\title{
First Cinematographic Encounter with the Ainu People
}

\author{
Centeno Martín Marcos P* \\ Department of East Asian Languages and Cultures, University of London, London, UK
}

Submission: June 18, 2018; Published: September 06, 2018

*Corresponding author: Centeno Martín, Department of East Asian Languages and Cultures, University of London, SOAS, London, UK, Email: mc100@soas.ac.uk

\begin{abstract}
The assimilation to Japanese culture suffered by the Ainu people during Meiji Period contrasted with the European fascination for this people. As a result, the Ainu were included in two of the earliest thirty-three sequences shot in Japan with the cinématographe. They were shot by the French operator François-Constant Girel for the Lumière brothers' catalogue in Les Aïnous à Yéso. This sequence reproduces a romantic exoticism that had been consolidated in 19th century photography, seeking to astonish Western audiences with images of people from another time. However, these earliest moving images also feature certain elements prior to the standardisation of pattern of representation of Ainu people in documentary film. As a consequence, Les Aïnous à Yéso becomes valuable material for research when studying these aspects that escaped the codification of Ainu visual representation.
\end{abstract}

Keywords: Ainu; Hokkaido; Ethnographic film; Japanese minorities; Lumière's Catalogue; François-Constant Girel; Visual representation; Primitive stage; Century; Indigenous people; Kuril Islands; Culture; Nation; Languages; GRASSI Museum

\section{Introduction}

This article interrogates the earliest cinematic representations of the Ainu people found in Les Aïnous à Yéso (1897) shot by French operator François-Constant Girel in the island of Hokkaido, Northern Japan, formerly known as Ezo or Yeso. This film is put into dialogue with the context in which it was made, seeking to nuance the kind of insight into the Ainu people it allows. This case study is assessed in relation to the codes of representation of the Ainu people in ethnographic images of the time. Thus, this research is aimed at finding common traits that cinema shared with $19^{\text {th }}$ century photography as well as framing the novelty brought by the cinematic medium at this primitive stage in the development of ethnographic documentary films.

\section{Invisibility Vs Fascination}

The Ainu people is an ethnic minority that has traditionally spread from northern Honshu and Hokkaido, in Japan to Kurile Islands, and South of Kamchatka Peninsula and Sakhalin island in current Russia. Their culture is an evolution from the Satsumon Culture $\left(8^{\text {th }}-13^{\text {th }}\right.$ century) with also strong influences from Okhotsk Culture -which dates to $7^{\text {th }}$ century and lasted until $11^{\text {th }}$ century in Hokkaido and $17^{\text {th }}$ century in the Kuril Islands-, mainly on Ainu spirituality, which is visible for example in the ceremony to send back bear spirits (iyomante rimse). The first historical documents that mention the Ainu date from around the $15^{\text {th }}$ century and at that time, the Ainu primarily kept a lifestyle based on fishing, hunting, gathering plants and trading with people from other areas (Figure 1). However, certain anthropological and genetic research suggests that the modern Ainu are ethnically linked to the Jōmon people, a proto-Mongolid population who settle in Japan more than 10.000 years ago $[1,2]$. Thus, the Ainu can also be regarded as descendants of the first inhabitants of the Japanese archipelago. In fact, Japanese Diet recognised the Ainu as the "indigenous people of Japan" in 2008, only one year after United Nations passed its "Declaration on the Rights of Indigenous People" [3]. Today, Ainu languages and culture courses are offered even far from Hokkaido, where most of Ainu population currently lives, at institutions such as Chiba University and Waseda University in Tokyo.

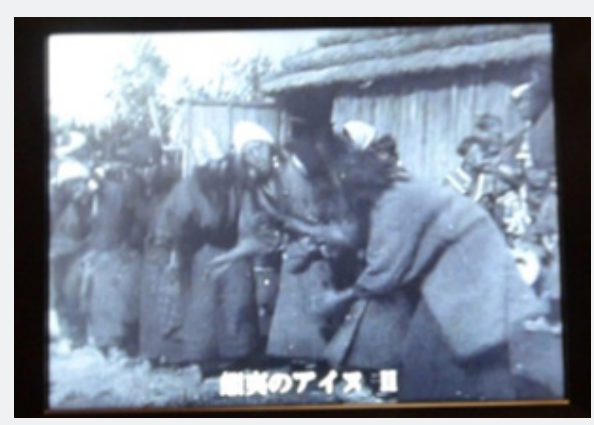

Figure 1: Ainu dance in Les Aïnous à Yésos.

This growing interesting in the Ainu in recent years comes after centuries of poverty and social exclusion. This 
discrimination occurred alongside cultural assimilation implemented since the beginning of Meiji Period (1868-1912) when Hokkaido and other areas traditionally inhabited by the Ainu were incorporated to the Japanese modern state. Ainu ceremonies and identity traits such as female tattoos and male earrings were banned from 1871, and Japanese government encouraged adapting Japanese lifestyle, based on farming, adopting Japanese names and acquisition of the Japanese language instead.

However, structural poverty and cultural assimilation contrasts with the fascination for the Ainu people in the West during this period. This was fuelled by the idea that the Ainu were the missing link between the European and East Asian peoples in the $19^{\text {th }}$ century. Their long beards, curly hair, big noses, eyes with epicanthic fold, among other physical traits prompted Western explorers to believe that the Ainu were a lost Caucasian people in the Far East -although modern studies reveal greater genetic relationship to Southeast Asians rather than western Eurasian people [4]. As a result, Ainu collections proliferated in museums and other European institutions such as the British Museum, the Musée d'Ethnographie de Neuchâtel in Switzerland, GRASSI Museum of Leipzig a Linden Museum of Stuttgart in Germany or the National Library of France in Paris.

The Ainu in Lumière'S Catalogue: Les Aïnous À Yéso (1897)

The Ainu were not only portrayed in hundreds of pictures taken by Western photographers but also by film operators. In fact, the Ainu are featured in two of the earliest thirtythree sequences of moving images shot in Japan with the cinématographe by the French cameraman François-Constant Girel. The new device developed by Lumière brothers had been brought to Japan by the industrialist Katsutarō Inabata who had studied with Auguste Lumière at the technical school of La Martinière in Lyon between 1877 and 1885. When Lumière brothers presented the cinématographe in Paris in December 1896, Inabata happened to be in France on a business trip and bought the rights of distribution of this invention in Japan and agreed to pay Lumière brothers $60 \%$ of the revenues. Inabata arrived in Kobe in January 1897 with several pieces of equipment and the operator Girel $[5,6]$.

Barely a month after the device was presented in Paris, Inabata Katsutarō alongside the then photographer Shibata Tsunekichi and French operators Girel and Gabriel Veyre, shot the earliest moving images (jidō-shashin) in Japan. Girel, who also was Lumière's distributor, exhibitor, operator and accountant, was more interested in making films rather than projecting them, was the one who filmed the Ainu during a trip to Hokkaido in October 1897. The sequence is entitled Les Aïnous à Yéso and belongs to the seventeen pieces that Girel shot for the Lumière catalogue until his return to France in December of that year. Today, this first film representation of the Ainu people can be seen at the permanent exhibition held in the National Film Centre of Tokyo.

This was not the first catalogue shot outside France. Lumière brothers sent operators to across the world to astonish audiences in France with exotic images from remote geographies. However, the pattern of representation of these actualités didn't differ too much from those early experiments undertaken in France. This is the reason why sequences such as the train entering Nagoya station shot by Girel resembled the famous L'Arrivée d'un train à La Ciotat shot by Lumière brothers in a village close to Marseille in December 1896.

\section{Patterns of Representation From $19^{\text {th }}$ Century Pho- tography}

Les Aïnous à Yéso was probably shot in Shiraoi, which had become a destination for explorers who sought an encounter with this people in the late $19^{\text {th }}$ century as it only required oneday trip from Sapporo, Hokkaido's capital city. Its inhabitants had familiarised themselves with the arrival of strangers and started to arrange exhibitions of their culture [7].

This scene is composed of two takes lasting no longer than a minute in total in which a group of men and women are shown separately dancing an Ainu dance. There are different kinds of dances (rimse, upopo o horippa), which are considered as one of the most representative elements of Ainu culture -UNESCO declared them cultural heritage in 2007. The camera is placed before a traditional Ainu house (chise) and featured men and women dressed in traditional garments. Among the portrayed men with long beards, one wears a paunpe, a crown made of wicker representing a bear's head.

These scenes projected a mythopoetic view of the Ainu people stuck in the past and linked to their ancestral customs reproducing codes of representation that can be found in the romantic exoticism created by the $19^{\text {th }}$ century ethnographic photography. Photos taken for example by Max Reich, Erwin Baelz and Graf von Linden, which are preserved at Linden Museum of Stuttgart in Germany, reveal common patterns of representation, mainly portrayals in frontal composition, featuring Ainu people dressed in traditional clothes, often men with paunge, sometimes fishing on an Ainu canoe (itaomacip) carved on large trunks, and women adorned with a traditional necklace (Tamasai) -significant differences can be found, however, in the photos taken on Sakhalin Ainu by the Polish anthropologist Bronislaw Pilsudsky, which are collected at the Musée d'Ethnographie de Neuchâtel in Switzerland, GRASSI Museum of Leipzig in Germany and National Library of France in Paris, whose study falls beyond the scope of this research.

However, these images contrast with the social reality of their protagonists. By the end of the 19th century, when Girel travelled to this island, the Meiji Restoration government had already been immersed in two decades of cultural and religious 
unification of the country. The notion of "nation" (kokka) was redefined under the emperor figure, compulsory education was established in the 1870s and Shinto was promulgated as a state religion. The Meiji slogan "Civilization and Enlightenment" (bunmei kaika) obscured an unprecedented process of assimilation of culture, language and lifestyle and therefore, these photos and early moving images were shot in a moment in which the represented was vanishing. These portrayals were misleading since they belonged to a non-existent world evoking an imagined and ritualized past.

Ainu culture was suffering from significant transformations also prompted by the Western influence. As a matter of fact, Girel had contacted the Ainu through French missionaries [8] as foreign missionary schools had been established in Hokkaido from the second half of the $19^{\text {th }}$ century and paradoxically, many Ainu educated in this time learned to write the Latin alphabet before Japanese [9]. Furthermore, part of the community was replacing animist beliefs with Christianity as well as Japanese Buddhism and Shinto. As a result, the apparent ethnic exoticism of Les Aïnous à Yéso contrasted with the rapid assimilation of the Ainu to Japanese and Western culture, language, religion and lifestyle [10].

The photomechanical images featuring the Ainu community overlooked these political, social and cultural changes in modern life. Unlike later newsreels developed few years later, these actualités were had an entertaining purpose rather than an informative role. Therefore, it is no wonder that none of these earliest thirty-three sequences made reference to vertiginous changes of all kinds that were taking place in Meiji Japan, which was a period of huge unrest that had started with a military uprising and a civil war followed by a process of modernisation in which the country shifted from a feudal to a modern state, inaugurating a new parliamentary system, with the first elected assembly by universal male suffrage in November 1890 . Yet, other pieces shot by Girel such as Danseuses Japonaises or Une Scène de Théatre Japonais depicted a nation of geishas and traditional theatre that was vanishing very quickly. This cinematographic mirage reveals limitations in the origins of cinema as well as in the cinema of origins to mirror social reality (Figure 2).

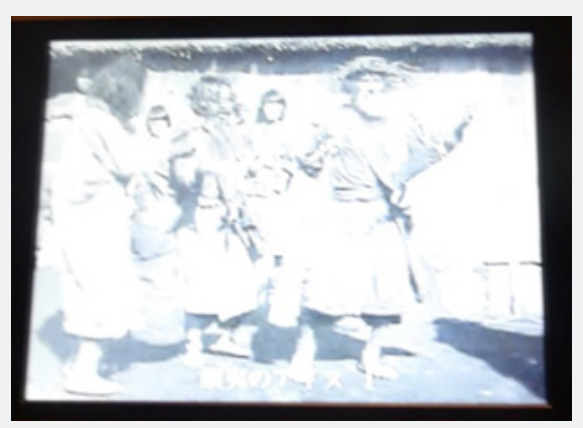

Figure 2: Male dances in Les Aïnous à Yéso (Constant Girel, 1897).

To interrogate Les Aïnous à Yéso, it is necessary to resort to the representations of the "primitive" inherited from adventurers and foreign missionaries' reports [11-13], ethnographic photography and engravings of the $19^{\text {th }}$ century. All of them were characterized by a distant gaze that did not try to denounce Ainu poverty or social exclusion or to explore further problems such as alcoholism [10]. Thus, cultural diversity in Japan was not to be explained but alienated to provoke fascination in the European viewer.

\section{Novelty in Moving Images}

However, despite this ethnographic usage of photography and cinema, moving images added some unseen aspects to the representation of the Ainu people. Girel modifies the frontal composition in the mise-en-scène in the second take and films from one side of the performance to take advantage of still primitive depth of field and portray all female characters into frame. They are dancing a rimse before the same Ainu traditional house. While Ainu used dances in communicating or playing with deities (kamui), asking for profitable hunting or dispelling bad spirits, the film does not specify which dance this mysterious performance belongs to. However, Girel briefly mentioned about these dances in one letter: We carried fruit, sweet potato and sweets to the Ainu, we chatted with them and they were so glad that they danced for us. There were two dances, an only woman "bird dance" and a male "warrior dance" [14].

It seems that when Girel talks about a "bird dance" he referred to the "crane dance" (sarorun chikap rimse). However, this dance is performed in circles, with the participants raising the upper part of their garments and shaking their arms as the crane's wingbeats. This does not occur in the dance captured on the film, in which women are shown gripping each other in line with their arms intertwined.

\section{Pre-Standardised Patterns of Representation}

Les Aïnous à Yéso is mysterious film presenting a mismatch with other later representations of the Ainu traditional culture. Another example can be found in the scene featuring the male characters that are dancing, singing and clapping their hands. While men are often portrayed participating in dances alongside women, danced performed by male groups alone are almost unseen in subsequent documentary films. This also calls into question some of the preconceived ideas about their culture. In fact, when the film was sent to Osaka for its first screening in summer 1898, it was presented as "Hokkaido Ainu Male Dance" (Hokkaido ainu dansei no odori), and in Nagoya it was entitled "Bear Dance of Ainu Hokkaido Indigenous" (Hokkaido dojin aino no kuma odori) [14]. Probably the male dance captured by Girel, what he referred to as "warrior dance", is a tapkara (literally "doing claps"), which is performed by elderly people during the Ainu bear ceremony, after the sacrifice of a cub.

Interestingly, the bear festival is one of the best-known ceremonies and a distinguishing mark of Ainu culture and it's not surprising that it was portrayed in several documentaries shot by Japanese and Western explorers: The first one was a 
festival filmed by the Russian-American Benjamin Brodsky in 1917, which was added to his Beautiful Japan (1918) and A Trip through Japan with the YWCA $(1919)[15,16]$. Few years later, Hatta Saburō also filmed it in his Life of Shiraoi Ainu (Shiraoi Ainu no seikatsu, 1926). Before World War II, two additional documentaries capture this ceremony, one shot by Inukai Tetsuo, Bear Festival in Chikabumi near Asahikawa-city (Kinbun no kumaokuri girei, 1936) and another one filmed by the Scottish doctor Neil Gordon Munro, Bear Festival in Chikabumi near Asahikawa-city (Kinbun no kumaokuri girei, 1936) [17]. However, in this first film representation of the Ainu, the dance is decontextualised, and no references to the bear ceremony are added to this piece.

Another interesting aspect that differs from later documentaries is the usage of jinbaoiri by the male characters. The jinbaori was a kimono shape garment originally used by Japanese samurai that the Ainu obtained through trading and became a traditional garment for them. However, most of the Ainu depicted in documentary films are dressed in other traditional kimono made of vegetable fibre (attus) and others made of cotton (ruunpe) with geometric designs. Even though like $19^{\text {th }}$ century photography, cinema kept conditioning the conception of who the Ainu are, there are certain elements in these first moving images that somehow escape from the standardised and ongoing codification of their visual representation.

\section{Conclusion}

In conclusion, these early cinematographic portrayals contain astonishing but misleading images if contemporary researchers intend to obtain any kind of ethnographic insight into the Ainu people. They are comprised by clichés and stereotypical representations originating from photographic portrayals. Girel's scenes portrayed traditions in decline that did not exist beyond the cinematographic screen. Assimilation and discrimination were ignored by cameramen, just like previous photographers and adventurers who reached Hokkaido in Meiji Period seeking to capture extraordinarily powerful images of individuals from another time.

However, despite acknowledging the existence of standardised patterns of representation, these earliest moving images reveal its contradictions. While the mise-en-scène in Les Aïnous à Yéso presents iconographic attributes that had already been codified by 19th century photography, it also contains interesting elements prior to the complete standardisation of the Ainu visual representation. Therefore, these scenes are manifestations whose relevance precisely relies on a narrative dysfunction. This first encounter of the Ainu with the cinematograph presents certain 'gaps' in the patterns of cultural representation. Girel shot these sequences in a moment in which the mecha- nisms of representation were not consolidated yet in the new cinematographic medium. Far from being an obstacle, these gaps in the representation are enriching objects of study as they were filmed before the portrayal of Ainu culture became completely standardised, packed and sold for cinematic consumption.

\section{References}

1. Hudson, Mark J (1999) Ruins of Identity: Ethnogenesis in the Japanese Islands. University of Hawaii Press, USA.

2. Atsushi Tajima (2004) Genetic origins of the Ainu inferred from combined DNA analyses of maternal and paternal lineages. American Journal of Human Genetics 49(4): 187-193.

3. Cotterill Simon (2011) Ainu Success: The Political and Cultural Achievements of Japan's Indigenous Minority. The Asia-Pacific Journal 9(12): 2.

4. Koppel Tom (2010) Lost World: Rewriting Prehistory. How New Science Is Tracing, Atria Books, New York, USA.

5. Dym Jeffrey A (2003) Benshi: Japanese Silent Film Narrators, and Their Forgotten Narrative Art of Setsumei. A History of Japanese Silent Film Narration, Lewiston, Edwin Mellen Press, New York, USA, p. 21-27.

6. Greenberg, Larry (2001) The Arrival of Cinema in Japan in The Benshi. Japanese Silent Films Narrators, edited by Matsuda Eigasha, Urban Connections, Tokyo, Japan, p. 6-12.

7. Sjöberg Katarina (1997) The return of the Ainu: cultural mobilization and the practice of ethnicity in Japan. $\left(2^{\text {nd }}\right.$ edn), Harwood Academic Publishers, Amsterdam, Netherlands, Europe, pp. 133-134.

8. Okada Kazuo (1999) The Ainu in Ethnographic Films. In: Ainu Spirit of a Northern People, edited by in Fitzhugh, William and Dubreuil, Chisato 0 (Eds.), Smithsonian Institution with University of Washington Press, Washington, USA, pp. 187-192.

9. Owell David L (2004) Making useful citizens of the Ainu. The Journal of Asian Studies 63(1): 5-29.

10. Siddle, Richard (1996) Race, Resistance and the Ainu of Japan. London, Routdledge, New York, USA, pp. 113-147.

11. Batchelor, John (1892) The Ainu of Japan: The Religion, Superstitions and General History of the Hairy Aborigines of Japan. Religious Tract Society, London, UK.

12. Howard, Benjamin Douglas (1893) Life with Trans-Siberian Savages. London, Longmans, Green, New York, USA.

13. Savage Landor, Arnold Henry (1893) Alone with the Hairy Ainu. J. Murray, London, UK.

14. Mitsuda, Yuri (1995) Girel to Veil, in Eiga denrai: shinumatogurafu to (Meiji no Nihon. Iwanami Shoten, Tokyo, Japan, p. 59.

15. Centeno Martín, Marcos P (2017) Failures of the Image: Backstage Look at the Early Film Portrayals of the Ainu People. Orientalia Parthenopea 17: 189-210.

16. Centeno Martín, Marcos P (2017) The Fight for the Self-Representation: Ainu Imaginary, Ethnicity and Assimilation, Aphaville. Journal of Film and Screen Media 13: 69-89.

17. Kreiner, Josef (1993) Seiyō no ainu kan no keisei: Yōroppa ni okeru ainu minzoku bunka no kenkyū to ainu kankei korekushon no rekishi ni tsuite, in Ainu no kōgei, Tokyo: Tokyo kokuritsu hakubutsukan, pp. $25-30$. 
(C) This work is licensed under Creative BY DOI: 10.19080/GJAA.2018.06.555690
Your next submission with Juniper Publishers

will reach you the below assets

- Quality Editorial service

- Swift Peer Review

- Reprints availability

- E-prints Service

- Manuscript Podcast for convenient understanding

- Global attainment for your research

- Manuscript accessibility in different formats

( Pdf, E-pub, Full Text, Audio)

- Unceasing customer service

Track the below URL for one-step submission https://juniperpublishers.com/online-submission.php 